\title{
PARTISIPASI MAHASISWA PROGRAM STUDI S1 ILMU KOMUNIKASI FHISIP UT PADA PROGRAM MOOCS PUBLIC SPEAKING YANG DIKEMBANGKAN UT
}

\author{
Nila Kusuma Windrati, Arifah Bintarti, Isma Dwi Fiani \\ Program Studi IImu Komunikasi, FHISIP, Universitas Terbuka \\ Email: nilakw@ecampus.ut.ac.id, arifahb@ecampus.ut.ac.id, \\ isma.fiani@ecampus.ut.ac.id
}

Received: 2021-02-15; Accepted: 2021-02-30; Published: 2021-03-10

\begin{abstract}
Abstrak
Massive Open and Online Courses (MOOC) Public Speaking (PS) adalah bentuk layanan pengabdian masyarakat yang dikembangkan UT secara online dan bersertifikat. Program ini mengajarkan pada pesertanya tentang praktik public speaking secara gratis dan bisa diikuti oleh siapapun yang berminat untuk mempelajari PS, termasuk mahasiswa Prodi S1 IImu Komunikasi FHISIP UT. Oleh karena itu, seharusnya mahasiswa Program Studi S1 IImu Komunikasi FHISIP UT memanfaatkan program yang ditawarkan UT tersebut dengan cara berpartisipasi mengikuti program tersebut. Penelitian ini bertujuan untuk mengetahui bagaimana partisipasi mahasiswa Program Studi S1 IImu Komunikasi FHISIP UT dalam program MOOC Public Speaking berserftifikat yang dikembangkan UT, yang dilihat dari peran aktif mereka dalam mencari informasi adanya program Moocs Public Speaking, dan peran aktif mereka dalam mengikuti proses pembelajaran dalam Moocs. Desain penelitian yang digunakan adalah deskriptif kualitatif, dengan metode pengumpulan data berupa survey dan wawancara mendalam. Adapun yang menjadi informan dalam penelitian ini adalah kelompok mahasiswa PS S1 IImu Komunikasi FHISIP UT yang mengikuti program Moocs PS pada tahun 2018-2019 sebanyak 2 orang dan Mahasiswa PS S1 IImu Komunikasi FHISIP UT yang telah/sedang mengambil matakuliah PS pada masa registrasi 2020.1. (10 orang). Temuan dalam penelitian ini adalah sebagai Berikut: 1). Temuan dari peserta moocs: mereka mendapatkan informasi program Moocss PS dari searching di website UT, Peserta Moocs PS aktif di program Moocs PS pada kelas diskusi, namun tidak aktif dalam pengerjaan tuga. 2). Temuan penelitian dari Mahasiswa Prodi S1 IImu Komunikasi yang tidak mengikuti Moocs PS: tidak ikut program Moocs PS karena tidak mengetahui adanya program Moocs PS.
\end{abstract}

Kata Kunci: MOOC; Public Speaking; Partisipasi

\begin{abstract}
Massive Open and Online Courses (MOOC) Public Speaking (PS) is a form of community service developed by UT online and certified. This program teaches participants about the practice of public speaking for free. Anyone can follow by interested in studying PS, including students of the S1 Communication Studies Study Program, FHISIP UT. Therefore, students of the S1 Communication Studies Program, FHISIP UT, should take advantage of the programs offered by UT by participating in the program. This study aims to find out how the participation of S1 Communication Studies students from FHISIP UT in the certified public speaking MOOC program developed by UT, which can be seen from their active role in seeking information on the Moocs Public Speaking program, and their functional role in participating in the learning process in Moocs. . The research design used is descriptive qualitative, with data collection methods in the form of surveys and in-depth interviews. As for the informants in this study, two groups of PS S1 Communication Studies students from FHISIP UT participated in the PS Moocs program in 2018-2019 and PS S1 Communication Studies students from FHISIP UT who have taken/are currently taking
\end{abstract}


PS courses during the 2020 registration period. (10 people). The findings in this study are as follows: 1). Results from MOOCs participants: they got information about the Moocs PS program from searching on the UT website; Moocs PS participants were active in the Moocs PS program in discussion classes but were not involved in doing assignments. 2). Research findings from S1 Communication Studies students who did not participate in the Moocs PS program: did not participate in the Moocs PS program because they did not know about the Moocs PS program.

Keywords: MOOC; Public Speaking; Participation

\section{PENDAHULUAN}

Massive Open and Online Courses (MOOC) Public Speaking adalah salahsatu Program Sertifikat Terbuka Online yang ditawarkan UT secarara gratis kepada masyarakat umum yang ingin mempelajari tentang teknik presentasi. Dengan berbasis Moodel dan bersifat ansyncrounus, program ini mengajarkan pada peserta MOOC tentang praktik public speaking. Harapanya, dengan mengikuti Program MOOC para peserta akan memperoleh kemampuan teoritis maupun praktis dalam bidang public speaking. Di era pasar global saat ini, adanya program MOOC Public Speaking bagi peserta tentunya sangatlah bermanfaat, khususnya bagi para lulusan atau mahasiswa yang sedang menempuh bidang ilmu komunikasi yang kelak akan bekerja di bidang komunikasi, termasuk mahasiswa Program Studi S1 Ilmu Komunikasi FHISIP UT, karena pada dasarnya pasar global menuntut para calon tenaga kerja untuk memiliki kompetensi sesuai bidang ilmu yang telah digeluti.

Terkait dengan kompetensi yang harus dimiliki calon tenaga kerja, hasil temuan penelitian sebelumnya yang dilakukan oleh Windrati, dkk (2016) tentang tuntutan KKNI, kemudian Asih, dkk (2017) tentang Pengembangan Model Praktik bagi mahasiswa Program Studi S1 IImu Komunikasi FHISIP UT, serta penelitian yang dilakukan oleh Bintarti, dkk (2017) tentang Kurikulum Program Studi S1 IImu Komunikasi FHISIP UT, diperoleh informasi bahwa mahasiswa Program Studi S1 IImu Komunikasi FHISIP UT merasa khawatir untuk mampu bersaing di pasar kerja setelah menyelesaikan pendidikanya di UT, karena mereka merasa belum memiliki kemampuan praktis bidang ilmu komunikasi selama menempuh pendidikan di UT. Selama ini memang kurikulum Program Stud S1 IImu Komunikasi FHISIP UT belum mengakomodasi tuntutan KKNI dalam hal praktik matakuliah, hal ini disebabkan karena system pembelajaran di UT yang sifatnya jarak jauh. Menurut Simonson, et.al (2012) salah satu kendala yang dihadapi oleh perguruan tinggi jarak jauh adalah lack of technology-enhanced classrooms, labs, or infrastructure. Sehingga dampaknya sulit untuk mengajarkan praktik untuk matakuliah yang sifatnya praktis seperti matakuliah public speaking. Dengan tidak adanya praktik yang tentunya berdampak terhadap kemampuan praktis mahasiswa, membuat mereka khawatir bila kelak tidak mampu bersaing di dunia kerja.

Kompetensi calon tenaga kerja dalam bentuk praktik sesuai bidang ilmu yang digeluti tentunya membutuhkan bukti formal yang diujudkan dalam bentuk sertifikat kompetensi. Menurut Linked in (2016) dengan dimilikinya sertifikat kompetensi, maka sesorang akan mendapatkan bukti pengakuan tertulis atas kompetensi kerja yang dikuasainya. Sertifikat tersebut bisa dikeluarkan oleh lembaga yang berwenang untuk 
menguji kompetensi, ataupun bisa juga dikeluarkan oleh organisasi penyelenggara program bersertifikat. Penelitian sebelumnya tentang KKNI (Windrati dkk., 2016), diperoleh informasi dari pakar kehumasan yang pada saat itu juga menjabat sebagai tim penilai sertifikasi kehumasan, bahwa untuk mendapatkan sertifikasi maka seseorang perlu mengikuti uji kompetensi melalui lembaga sertifikasi yang resmi disyahkan oleh pemerintah, namun bila yang bersangkutan telah memiliki bukti sertifikat yang dikeluarkan oleh lembaga terpercaya, dan pihak lembaga sertifikasi telah menguji kebenaran sertifikat tersebut, maka maka menurut pakar tersebut, yang bersangkutan tidak perlu lagi mengikuti uji kompensi. Program MOCC yang diselenggarakan UT adalah program MOOC bersertifikat, sehingga dengan adanya sertifikat tersebut, para peserta MOOC bisa memanfaatkanya sebagai lampiran kompetensi yang dimiliki saat mendaftarkan diri sebagai calon tenaga kerja.

MOOC Public Speaking sebagai program bersertifikat, pertama kali dikembangkan dan ditawarkan oleh UT pada tahun 2014, dan hingga tahun 2019 program tersebut masih ditawarkan. Dalam pelaksanaanya, Program MOOC Public Speaking diberikan dalam 4 kali pertemuan selama 6 minggu pada tiap semester. Setiap pertemuan, dilengkapi dengan inisiasi berupa materi public speaking dan forum diskusi yang dapat digunakan peserta MOOC untuk bertanya jawab dan bertukar informasi/pengalaman sesuai topik diskusi. Pada beberapa inisiasi, juga dilengkapi dengan video public speaking yang diambil dari berbagai sumber, guna memperjelas praktik public speaking. Peran aktif peserta MOOC dalam forum diskusi akan diberi nilai oleh tutor. Selanjutnya, di akhir pertemuan, yaitu pertemuan ke 4, peserta MOOC diberi tugas untuk menguji kompetensi mereka tentang Public Speaking, yaitu berupa praktik public speaking yang direkam dalam bentuk video oleh peserta MOOC, kemudian diupload di halaman tugas. Selain itu, peserta MOOC juga diberi tugas membuat materi pendukung presentasi dalam bentuk PowerPoint, yang juga harus diupload di halaman tugas. Tugas yang dibuat oleh mahasiswa tersebut kemudian diberi masukan dan dinilai oleh tutor. Hasil penilaian dari diskusi dan tugas akan menentukan apakah peserta MOOC layak diberi sertifikat MOOC atau tidak. Peserta MOOC yang berhak mendapatkan sertifikat MOOC adalah peserta yang mendapatkan nilai 60 ke atas dari hasil penjumlahan nilai tugas dan diskusi.

Bila di satu sisi, mahasiswa Program Studi S1 IImu Komunikasi merasa belum memiliki kompetensi praktis Public Speaking, sedangkan di sisi lain ada Program MOOC Public Speaking bersertifikat yang mengajarkan praktik public speaking yang ditawarkan UT secara gratis, maka seharusnya mahasiswa Program Studi S1 Illmu Komunikasi FHISIP UT banyak yang memanfaatkan dan berpartisipasi dalam program MOOC tersebut. Oleh karena itu, menarik untuk dikaji tentang partisipasi mahasiswa Program Studi S1 IImu Komunikasi FHISIP UT dalam Program MOOC Public Speaking bersertifikat yang dikembangkan UT.

Berdasarkan latar belakang yang telah dikemukakan, maka yang menjadi rumusan masalah dalam penelitian ini adalah bagaimana partisipasi mahasiswa Program Studi S1 IImu Komunikasi FHISIP UT dalam program MOOC Public Speaking berserftifikat yang dikembangkan UT? Hasil penelitian ini diharapkan bisa digunakan UT untuk menyempurnakan program MOOCs Public Speaking yang telah dikembangkan. 
Konsep dan teori yang digunakan dalam penelitian ini adalah konsep tentang partisipasi dan MOOCS. John M. Echols dan Hasan Shadly dalam (Maswandi 2010) menyampaikan hal yang sama, yaitu partisipasi diartikan sebagai pengambilan bagian, pengikut sertaan. Jika dua pengertian tersebut diterapkan pada penelitian ini maka partisipasi mahasiswa Program Studi S1 ilmu Komunikasi pada Program MOOC Public Speaking dapat dimaknai sebagai keikutsertaan mahasiswa terhadap program tersebut.

MOOC merupakan pembelajaran atau perkuliahan yang diselenggarakan secara online dengan tujuan agar dapat diikuti oleh sejumlah besar peserta dengan cara mengakses web yang berisi bahan bacaan, video perkuliahan dan tugas-tugas yang dapat memfasilitasi perserta mencapai kompetensi yang ditawarkan (Pribadi, 2017). Sedangkan menurut Mora (2013) yang dimaksud dengan MOOc adalah kursus online tidak berbayar dan sifatnya terbuka, dengan mengintegrasikan jejaring sosial, sumber daya online yang dapat diakses, dan difasilitasi oleh praktisi bidang studi. MOOC dibangun didasarkan atas keterlibatan peserta didik, sehingga dengan MOOC peserta didik bisa mengatur sendiri partisipasi mereka sesuai dengan tujuan pembelajaran, pengetahuan dan keterampilan sebelumnya, dan minat yang sama

\section{METODE}

Penelitian ini menggunakan metode penelitian deskriptif kualitatif untuk mendeskripsikan bagaimana partisipasi mahasiswa program studi S1 IImu Komunikasi FHISIP UT pada Program MOOC Public Speaking bersertifikat yang dikembangkan UT. Data dikumpulkan dengan menggunakan metode survei dan wawancara mendalam. Moleong (2005) menyatakan wawancara mendalam adalah proses penggalian informasi secara mendalam, terbuka, dan bebas dengan masalah dan fokus yang ingin digali dari penelitian yang dilakukan. Dalam hal ini metode wawancara mendalam yang dilakukan mengacu kepada daftar pertanyaan yang telah dipersiapkan sebelumnya.

Informan penelitian ini dipilih secara purposif sesuai kebutuhan peneliti. Kriteria pemilihan informan berdasarkan dua kelompok mahasiswa Program Studi S1 IImu Komunikasi yaitu pertama, kelompok yang pernah mengikuti program MOOC Public Speaking yang ditawarkan UT. Kedua, belum pernah mengikuti Program MOOC Public Speaking yang dikembangkan UT, namun pada masa registrasi 2019.1 sampai dengan 2020.1 telah/sedang mengambil matakuliah public speaking.

Wawancara mendalam juga dilakukan terhadap penyelenggara MOOC, yaitu pihak pengelola program MOOC serta tutor MOOC Public Speaking, guna memperoleh data pendukung untuk memperkuat temuan hasil wawancara dengan mahasiswa yang terpilih sebagai informan.

Sedangkan survei dilakukan dengan menyebarkan kuesioner pada kelompok peserta Moocs tahun 2018-2019 sebanyak 25 orang. Dari 25 orang tersebut, hanya 2 orang yang berasal dari Prodi S1 IImu Komunikasi FHISIP UT. 2 orang tersebut yang kemudian dijadikan informan penelitian dari kelompok mahasiswa Prodi S1 IImu Komunikasi FHISIP UT yang mengikuti program Moocs Public Speaking. Namun demikian 23 orang lainya datanya tetap digunakan untuk memperkuat temuan penelitian 


\section{HASIL PENELITIAN DAN PEMBAHASAN}

Pada bagian ini disampaikan tentang penelitian partisipasi mahasiswa Program Studi S1 IImu Komunikasi FHISIP UT dalam Program MOOCS Public Speaking yang dikembangkan UT. Partisipasi dilihat dari ikut tidaknya mahasiswa pada program tersebut. Untuk mahasiswa yang ikut program MOOS Public speaking dilihat berdasarkan: dari mana mereka mengetahui adanya program Moocs, partisipasi dalam forum diskusi dan pengerjaan tugas, aksesibilitas mereka pada program Moocs Public Speaking (tingkat keseringan, dan lama akses), serta alasan mereka mengikuti program tersebut. Data dari mahasiswa yang mengikuti program Moocs Public speaking akan didukung dengan data yang diperoleh dari peserta Moocs Public Speaking yang bukan dari mahasiswa Program Studi S1 IImu Komun ikasi. Sedangkan dari mahasiswa yang tidak mengikuti program MOOCS dikum pulkan data tentang alasan mereka tidak ikut dan harapan mereka dengan adanya program Moocs Public Speaking. Temuan dari penelitian tersebut adalah sebagai berikut:

Partisipasi Mahasiswa Program Studi S1 IImu Komunikasi FHISIP UT pada Program Moocs dari Kelompok Mahasiswa Peserta Moocs.

Informasi dari mana mahasiswa mengetahui adanya Program Moocs. Terkait darimana informan penelitan mengetahui adanya program Moocs, semua informan $(100 \%)$ mengatakan bahwa mereka memperoleh informasi dari website UT. Hal ini benarnya adanya karena menurut informasi dari pihak pengelola Moocs, selama ini Mooccs diinformasikan pada masyarakat umum, termasuk pada mahasiswa UT melalui website UT dan website LPPM UT. Di website UT informasi tersebut dipasang di halaman muka website UT dan juga di halaman informasi akademik, sebagaimana terlihat dalam gambar 1 di bawah ini:

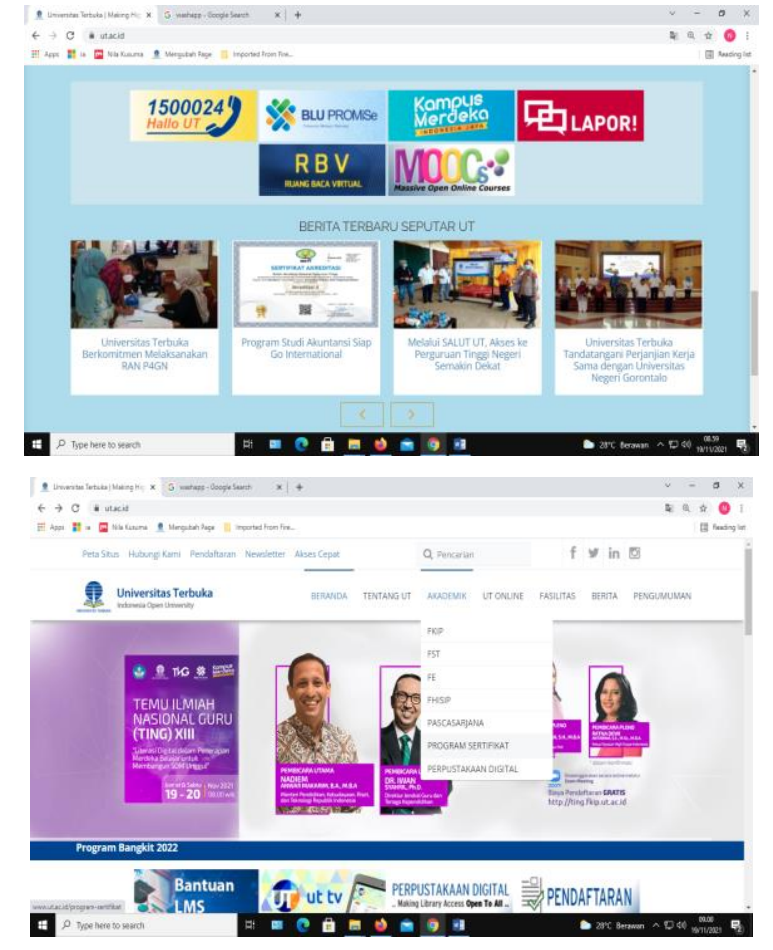

Gambar 1. Tampilan Moocs di website UT

Sedangkan informasi tentang program Moocs Public Speaking yang disampaikan melalui website LPPM UT dapat dilihat pada gambar 2 berikut ini: 


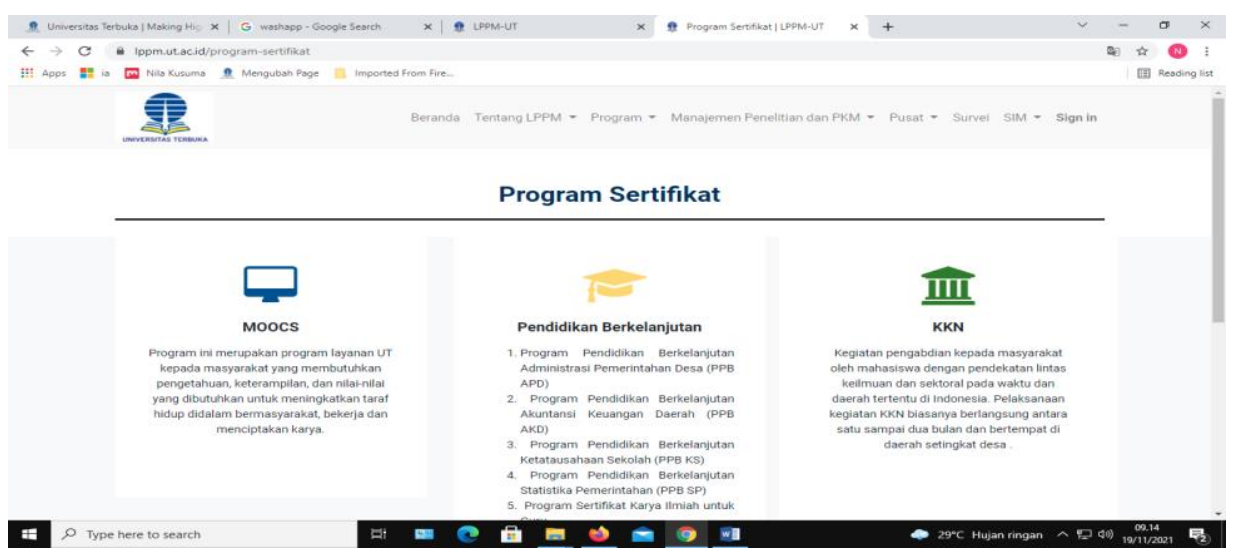

Gambar 2. Tampilan Moocs di website LPPM

Namun dalam pelaksanaanya, banyak mahasiwa Program Studi S1 Ilmu Komunikasi FHISIP UT yang tidak tahu tentang program Moocs Public Speaking yang dikembangkan UT. Hal ini dikemukakan oleh informan bahwa banyak mahasiswa Prodi IImu Komunikasi FHISIP UT yang tidak tahu adanya program tersebut, sehingga informan menyarankan untuk untuk bisa dipublikasikan secara luas lagi program tersebut, karena menurut informan, program ini bagus bagi mahasiswa.

Partisipasi dalam forum diskusi dan pengeraan tugas. Peran aktif informan dalam forum diskusi semua terkategori aktif karena mereka memberikan pendapat di setiap diskusi, bahkan mereka sempat melakukan perbaikan terhadap mereka jika mereka merasa belum maksimal dalam memberikan pendapat, atau mendapat masukan dari tutor terkait pendapat mereka. Sedangkan dalam pengerjaan tugas, semua informan $(100 \%)$ tidak mengerjakan tugas. Sebagai informasi, tugas yang diberikan tutor pada program Moocs public speaking yang ditawarkan pada tahun 2018-2019 berupa pembuatan materi pendukung presentasi dalam bentuk PPT dan melakukan rekaman presntasi dalam kemasan video. Tugas bisa dikerjakan mahasiswa dalam kurun waktu 1 minggu. Namun dalam pelaksanaanya, tidak hanya informan saja yang tidak mengejrakan tugas, tetapi sebagian besar peserta program tersebut (18 orang) tidak mengerjakan tugas, dan hanya 5 orang yang mengerjakan tugas. Alasan mereka tidak mengerjakan tugas adalah kesibukan kerja dan kendala akses. Pada program Moocs public speaking, upload tugas sudah disiapkan di halaman tugas oleh tutor, namun berdasarkan informasi dari beberapa peserta untuk upload tugas mereka mengalami kesulitan, sehingga membuat mereka tidak mengumpulkan tugas. Ada [un 5 orang yang mengerjakan tugas adalah mereka yang berinisiatif mengumpulkan tugas melalui email Tutor. Pada program Moocs memang data tutor dilengkapi dengan alamat email, sehingga memungkinkan bagi peserta untuk menghubungi tutor melalui emailo jika mereka menghadapi kendala dalam kegiatan moocs.

Aksesibilitas. Aksesibilitas dilihat dari tingkat keseringan akses, durasi membuka program dan pengerjaan tugas serta diskusi. Peserta dikatakan sering akses jika membuka program lebih dari 4 kali, karena Program Moocs Public Speaking ang ditawarkan pada tahun 2018-2019 disampaikan dalam 4 sesi pertemuan, artinya jika mahasiswa lebih dari 4 kali akses berarti mereka mengikuti semua sesi pertemuan. terkiat tingkat keseringan akses diperoleh informasi bahwa 100\% informan tergolong sering akses karena mereka lebih dari 4 kali mengakses program. Informan mengatakan bahwa memperbaiki pendapat di forum diskusi yang menjadikan mereka 
akses lebih dari 4 kali. Memang dalam pelaksanaan program Moocs, khususnya di sesi diskusi, pendapat mahasiswa akan direspon oleh tutor, dan tutor memberi kesempatan pada peserta untuk memperbaiki pendapat mereka jika dirasa pendapat mahasiswa kurang tepat. Kesempatan ini digunakan oleh informan untuk memperbaiki pendapat mereka sebelumnya.

Adapun durasi membuka program, seluruh informan (100\%) mengatakan bahwa rata-rata mereka mengakses program antara 30-60 menit. Durasi ini bisa dikategorikan tinggi karena tiap sesi Moocs yang ditawarkan pada tahun 2018-2019 hanya berisi materi inisiasi sekitar 1 halaman, video rekaman, dan forum diskusi. Sehingga jika hanya untuk melihat, mempelajari dan aktif di diskusi tidak terlalu membutuhkan waktu banyak.

Adapun alasan yang dikemukakan informan terkait keikutsertaan mereka dalam program Moocs adalah karena tuntutan kerja, ingin memperoleh keterampilan Public speaking dan ingin memperoleh sertifikat Public Speaking. Alasan ini juga dikemukakan oleh sebagian beserta peserta Moocs. Hal ini bisa dipahami, karena pada saat ini tuntutan kerja mensyaratkan tenaga kerja untuk memiliki kompetensi sesuai bidang ilmu yang digeluti, serta ditunjukan dengan sertifikat sebagai bukti kompetensi yang mereka miliki. Oleh karena itu tepat kiranya jika informan mengatakan bahwa factor-faktor tersebut yang menjadi alasan mereka mengkuti program Moocs Public Speaking.

Partisipasi Mahasiswa Program Studi S1 IImu Komunikasi FHISIP UT pada Program Moocs dari Kelompok Mahasiswa Bukan Peserta Moocs. Pada kelompok ini dikumpulkan data terkait mengapa mereka tidak mengikuti program Moccs public Speaking, dana apa harapan mereka tentang program Moocs Public Speaking

Alasan informan tidak ikut Mooc s public Speaking. Terkait ketidak ikutan informan pada program Moocs Public speaking, semua informan (100\%) mengatakan bahwa mereka tidak tahu adanya program tersebut. mereka baru mengetahui saat mereka diminta menjadi informan dalam penelitian ini. Sebagaimana dikemukakan di atas bahwa program ini dipublikasikan melalui website UT dan website LPPM UT. Untuk website UT Informan mengatakan bahwa mereka sering membuka website UT tetapi tidak mengetahui bahwa ada program tersebut yang ditawrkan melalui website UT. Mereka membuka websit UT lebih untuk membuka kalender akademik dan membuka perpustakaan digital milik UT. Dan mereka menyayangkan tidak tahu ada program tersebut, karena menurut mereka public speaking merupakan keterampilan yang harus dikusasi mahawsiswa Program studi S1 ilmu Komunikasik, sehingga dengan adanya Moocs bisa mereka jadikan sarana untuk belajar public speaking secara praktis, apalagi program tersebut dilengkapi dengan adanya sertifikat.

Banyaknya mahasiswa Program Studi S1 ilmu Komunikasi yang tidak tahu dan tidak mengikuti program tersebut tentunya sangat disayangkan, mengingat pada beberapa penelitian sebelumnya yang dilakukan oleh peneliti terkait kompetensi mahasiswa program Studi S1 IImu Komunikasi, diperoleh informasi bahwa mahasiswa Prodi S1 IImu Komunikasi FHISIP UT merasa tidak memiliki kemampuan praktik public speaking selama mereka menempuh pendidikan di UT, dan mereka sangat berharap matakulaih public speaking dilengkapi dengan praktik.

Oleh karena itu, informan menyarankan alangkah baiknya program Moocs Public Speaking disosialisasikan tidak hanya lewat website UT tetapi juga media lainya, 
khususnya yang banyak diakses mahasiswa, seperti melalui tutorial online (tuton), Instagram dan media social lainya yang dikelola UT. Dari hasil pengamatan peneliti, pada tahun 2015 program Moocs juga disosialisasikan tidak hanya melalui website UT tetpai juga melalui twitter dan facebook yang dikelola UT. Namun untuk untuk ini, menurut pihak pengelola program, Moocs, sosialisasi Moocs hanya dilakukan melalui website UT dan website LPPM UT. Sedangkan menurut informan, mereka tidak mengetahu tentang website LPPM, sehingga tidak pernah membuka website tersebut.

Harapan informan terhadap program Moocs public Speaking. Informan pada kelompok ini adalah informan yang belum perna mengikuti program Moocs Public Speaking, namun demikian harapan mereka program Moocs Public speaking benarbenar mengajarkan praktik public speaking, sehingga peserta Moocs bisa memperoleh keterampilan public speaking melalui program ini. Mereka berharap program Moocs mengajarkan berbagai metode presentasi dengan contoh-contoh praktik yang sesuai yang bisa memperkaya pengetahuan dan keterampilan mereka dalam bidang public speaking. Sehingga ketika peserta Moocs memiliki sertifikat Moocs Public Speaking yang dikeluarkan UT, maka memang mencerminkan kemampuan mereka dalam bidang Public Speaking, karrena menurut informan ini akan membawa reputasi UT di dunia kerja. Harapan ini sesuai dengan harapan peserta moocs yang bukan dari kelompok mahasiswa Program Studi S1 Ilmu Komunikasi. Sebagian bbesar dari peserta Moocs memberi masukan agar program Moocs Public Speaking lebih diperbanyak contoh-contoh dan kegiatan-kegiatan praktik public speaking

\section{KESIMPULAN}

Berdasarkan bab pembahasan di atas, maka dapat dibuat beberapa kesimpulan. Pertama, sangat sedikit mahasiswa Prodi S1 Ilmu Komunikasi FHISIP UT yang mengikuti Program Moocs PS karena banyak mahasiswa yang tidak mengetahui program tersebut. Kedua, kurangnya sosialisasi program Moos PS. Ketiga, mahasiswa yang mengikuti program Moocs PS berpartisipasi secara aktifdalam kelas diskusi, baik dari sisi intensitas maupun durasi waktu akses. namun tidak aktif di kelas tugas. Keempat, keikutsertaan dalam Program Moocs PS karena untuk mendapatkan keterampilan PS, mendukung pekerjaan, mendapatkan sertifikat. Berdasarkan kesimpulan tersebut, penelitian ini membeirikan beberapa saran untuk pengembangan Program Moocs PS. Pertama, perlu ditingkatkan sosialisasi program Moocs melalui berbagai media yang dimiliki UT. Kedua, perlu dilakukan evaluasi dan peningkatan Progrma Moocs Public Speaking dengan mengacu hasil temuan penelitian ini.

\section{REFERENSI}

Asih, Irsanti Widuri, Arifah Bintarti, Nila Kusuma Windrati. 2017. Pengembangan Model Matakuliah Praktik Untuk PS S1 IImu Komunikasi FHISIP UT. Laporan Penelitian. LPPM. UT. Jakarta.

Bintarti, Arifah, dkk. 2017. Pengembanagn Kurikulum Yang Selaras Dengan Kerangka Kualifikasi Nasional Indonesia(Kkni) Pada Program Studi S1 IImu Komunikasi. Laporan Penelitian. LPPM. UT. Jakarta 
Hendrayani dan Dharmawan, Yohana Purnama. 2014. Public Speaking. Buku Materi Pokok. Universitas Terbuka. Jakarta

Pribadi, Bennny A. 2017. Media Teknologi dalam Pembelajaran. Kencana. Jakarta

Windrati, Nila Kusuma, dkk. 2016. Tuntutan KKNI Dalam Pengembangan Kompetensi Program Program Studi S1 IImu Komunikasi FISIP-UT. Laporan Penelitian. LPPM. UT. Jakarta

Lembaga Sertifikasi Profesi Jaminan Mutu dan Keamanan Pangan. 2016. BNSP menuju Indonesia yang kompeten. Diakses dari https://id.linkedin.com/pulse/bnsp-menuju-indonesia-yang-kompeten-lsp, pada tanggal 24 januari 2018.

MOOCs.ut.ac.id diakses pada tanggal 13 Februari 2018.

Bates, Tony. 2014. What Is A MOOC?. Online Learning and Distance Education Resources. Diakses dari https://www.tonybates.ca/2014/10/12/what-is-a-mooc/ pada tanggal 30 januari 2020.

Mora, Sergio Lujan. 2013. What is A MOOC. Diakses dari http://desarrolloweb.dlsi.ua.es/moocs/what-is-a-mooc pada tanggal 30 Januari 2020.

Simonson, Michael et.al. (2012). Teaching and Learning at a Distance. Fifth Edition. Pearson Education, Inc. Boston, MA

(C) 2021 by the authors. Submitted for possible open access publication under the terms and conditions of the Creative Commons Attribution (CC $\quad$ BY $\quad$ SA) license (https://creativecommons.org/licenses/by-sa/4.0/). 